2008

\title{
Incorporating International Human Rights Law in National Constitutions: The South African Experience
}

Penelope Andrews

New York Law School, penelope.andrews@nyls.edu

Follow this and additional works at: https://digitalcommons.nyls.edu/fac_articles_chapters

\section{Recommended Citation}

Andrews, Penelope, "Incorporating International Human Rights Law in National Constitutions: The South African Experience" (2008). Articles \& Chapters. 1291.

https://digitalcommons.nyls.edu/fac_articles_chapters/1291 


\title{
Incorporating International Human Rights Law in National Constitutions: The South African Experience
}

\author{
By Penelope E. Andrews
}

\section{A. Introduction}

In his 1931 lectures at the University of Idaho College of Law, Professor Manley $O$. Hudson reflected on the benefits and possibilities of a global legal order. His vision was one in which the global community of states engaged with, and relied upon, the imprimatur of international law. ${ }^{1}$ This vision incorporated the idea of the United States as a good global citizen, generating an international agenda of human rights and good governance. ${ }^{2}$ Even though Professor Hudson's insights predated the establishment of the United Nations and the drafting of the Universal Declaration of Human Rights, his sentiments were very much in line with those that spurred the creation of the modern international legal order.

The focus of this book is partly to revisit that vision, and partly to explore the universal ramifications of that vision. What I intend to do in this chapter is to assess the challenge of incorporating and applying international law within national legal frameworks, and more specifically international human rights law, by examining one case study, namely, South Africa. In particular, I will examine how this newly democratized country has incorporated international law into its national legal framework, and the possibilities for democracy and human rights that are generated by such incorporation.

This examination is important because the transition from apartheid to democracy in South Africa was of momentous global significance. This democratic transformation, from a country steeped in authoritarianism and racism, to one predicated on international human rights principles, including peaceful co-existence, ${ }^{3}$ transparency and accountability, involved the international community at all stages. ${ }^{4}$ The struggle

1 See generally Manley O. Hudson, Progress in International Organization (1932).

2 Id. at 103-117.

3 Azanian Peoples Org. (AZAPO) v. The President of the Republic of S. Afr. 1996 (4) SALR 637 (CC) at para. 3 (S. Afr.) (stating, "[t]he Constitution provides a historic bridge between the past 
against apartheid had an enormous impact on the development of international human rights law, specifically the evolving international principles geared toward the proscription of apartheid and racism. ${ }^{5}$ Indeed, apartheid was declared a crime against humanity by the United Nations in $1966 .{ }^{6}$ Moreover, the struggle against racism and for self-determination, pursued mostly by formerly colonized communities, was informed by global abhorrence to the policies of apartheid, as illustrated by the numerous resolutions passed by the United Nations against the apartheid government. ${ }^{7}$ The post-apartheid democratic state became the first to incorporate international human rights principles into its Constitution, and into the structure of its system of governance. ${ }^{8}$

This chapter assesses the human rights project in South Africa by examining first, how international law has been incorporated in South Africa's Bill of Rights. Second, this chapter explores the interpretation of these rights by the South African Constitutional Court, and more specifically, how the Court has embraced international human rights principles in its jurisprudence. This exploration also involves examining the strategic choices made by the Court as to how it will adopt those principles and under what conditions, as well as when it chooses to reject those international human rights principles in favor of a localized reading. Finally, this chapter concludes by examining some lessons to be learned from this experience, and in particular how the adoption of international legal principles by the South African Constitutional Court may provide lessons for countries both similarly and differently situated.

of a deeply divided society characterized by strife, conflict, untold suffering and injustice, and a future founded on the recognition of human rights, democracy and peaceful co-existence ...").

4 See generally, Louis B. Sohn, Rights in Conflict: The United Nations and South Africa (1994).

-Id, See also Henry J. Richardson, Self-Determination, International Law and the South African Bantustan Policy, 17 Colum. J. Transnat'L L. 185 (1978); Edgar Brookes, Apartheid (1968); Brian Bunting, The Rise of the South African Reich (1986); Arthur J. Goldberg, The Status of Apartheid Under International Law, 13 Hastings Const. L. Q. 1 (1985).

6 International Convention on the Suppression and Punishment of the Crime of Apartheid, Nov. 30, 1973, 1015 U.N.T.S. 243.

7 Kevin Hopkins, Assessing the World's Response to Apartheid: A Historical Account of International Law and its Part in the South African Transformation, 10 U. Miami INT'L \& Comp. L. Rev. 241 (2001-2002). See, e.g., Decade for Action to Combat Racism and Racial Discrimination, G.A. Res. 3057 (XXVIII), U.N. Doc. AVCONF.119/15 (Nov. 2, 1973). See, e.g., Resolution Against Apartheid in Sports G.A. Res. 40/64, U.N. Doc. A/40/53 (Dec. 10, 1985).

8 For a detailed exploration of the Sauth African Constitution, see generally, The Post AparTheid Constirutions (Penelope Andrews \& Stephen Ellmann, eds., 2001). 


\section{B. From Apartheid to Democracy}

The period preceding the establishment of the United Nations involved a brief moment of global optimism, one that also involved South Africa. Indeed, Jan Smuts, the Prime Minister of South Africa at the time, was President of the Committee on the General Assembly of the United Nations, and served as a principal drafter of the Charter of the United Nations. ' But South Africa's positive involvement in this exercise of global governance was shortlived. In 1948, the Nationalist Party came to power in South Africa on a platform of white supremacy, embarking on a Kaf kaesque project to separate the citizens of South Africa according to clearly demarcated racial groups. ${ }^{10}$ This project was bolstered by a legal system designed to ensure that all aspects of life, including work, marriage, education, health, and travel, were rigidly regulated. ${ }^{11}$ In addition, a brutal security and police apparatus made certain that these laws were obeyed and that political dissent was stifled. ${ }^{12}$ A cursory reading of the volumes of the reports of the South African Truth and Reconciliation Commission bear testimony to the grotesque lengths the apartheid government went, to ensure that the system was reinforced. ${ }^{13}$

This system of apartheid increasingly became of concern to the global community, even as the apartheid government was hiding behind the principle of state sovereignty. ${ }^{14}$ Indeed, it is arguable that the state-centric model of international law confronted some challenge, as the United Nations and many governments across the world began to recognize the anti-apartheid opposition movements, and particularly the African National Congress and the Pan-Africanist Congress,

2 SoHN, supra note 4.

10 In pursuit of this goal, the apartheid government passed a series of statutes to institutionalize racial discrimination. These statutes included: Population Act of 1950; Prohibition of Mixed Marriages Act of 1949; Group Areas Act of 1950; The Reservation of Separate Amenities Act of 1959. See Apartheid: The Facts, International Defence and Aid Fund (1982) thereinafter Apartheid: The Facts].

11 Apartheid: the Facts, supra note 10.

12 See generally, John Dugard, Human Rughts and the South Aprican Legal Order (1982); see also International Commission of Jurists, South Aprica: Human Rights and the Law (Geofrey Bindman ed., 1988).

13 See Truth and Reconciliation Commission, Final Report, http://www.doj.gov.za/trc/report/ execsum.htm. See also, Penelope E. Andrews, Reparations for Apartheid's Victims: The Path to Reconciliation?, 53 Depaul L. Rev. 1155 (2004); Kader Asmal, et al., Reconciliation Through Truth: A Reckoning of Apartheid's Criminal Governance (2d ed. 1997).

14 See African National Congress, Submission to the Truth and Reconciliation Commission, http:// www.anc.org.za/ancdocs/misc/trc03.html; see also Jacquie Cassette, Towards Justice in the Wake of Armed Conflicts? The Evolution of Warm Crimes Tribunals, 9 African Security Review (2000), http://www.iss.co.za/pubs/ASR/9No5And6/Cassette.html\# Anchor-Convention-9012. 
as representing the majority of South Africans. ${ }^{15}$ In addition, once apartheid was deemed a crime against humanity by the United Nations, ${ }^{16}$ the constant objections of the South African government to the international consensus against apartheid, could not relieve it of its duty to abide by the new international norms. Apartheid South Africa is a commonly cited example for the international law principle that the persistent objector rule does not apply where the customary international law involves a jus cogens norm. ${ }^{17}$

The international struggle against apartheid underpinned the global fight against racism. Many key documents of international human rights law proscribing racism, most specifically the International Convention of Elimination of All Forms of Racism, ${ }^{18}$ were developed in response to apartheid. Indeed Henry Richardson, ${ }^{19}$ Louis Sohn ${ }^{20}$ and John Dugard ${ }^{21}$ have in their scholarship traced the link between international law and apartheid. ${ }^{22}$

At the end of the 1980s and the beginning of the 1990s, when the end of apartheid became inevitable, negotiations commenced in South Africa about the shape of the future constitutional democracy. These negotiations centered on a range of issues relevant to democratic governance, including the question of human rights. The general consensus about the inclusion of civil and political rights in a Bill of Rights was established immediately. ${ }^{23}$ This was not surprising, in the wake of apartheid and its systematic denial of a range of civil and political rights.

The consensus about the inclusion of social and economic rights, and in particular, their justiciability, came later. For despite the recognition that the processes of apartheid had effectively institutionalized economic inequality, and that the majority of black South Africans languished in poverty, there was not general agreement about how to attain economic equity. ${ }^{24}$

15 See G.A. Res. 37/69, U.N. Doc. A/RES/37/69 (Dec. 9, 1982) (calling on the international community to reaffirm "the legitimacy of the oppressed people of South Africa and their national liberation movement ....".).

16 International Convention on the Suppression and Punishment of the Crime of Apartheid, Nov. 30, 1973, 1015 U.N.T.S. $243,246$.

17 See Jonathan I. Charney, The Persistent Objector Rule and the Development of Customary International Law, 56 BRIT. Y.B. INT'L L. 1 (1985).

${ }^{18} 660$ U.N.T.S. 195 (entered into force Jan. 4, 1969).

19 See, e.g., Henry J. Richardson, Self-Determination, International Law and the South African Bantustan Policy, 17 Colum. J. of Transnat'z L. 185 (1978)

20 See SoHN, supra note 4.

21 See Dugard, supra note 12.

22 For a thoughtful discussion on apartheid and international law, see Goldberg, supra note 5.

${ }^{23}$ See The Small Miracle: Sout'i Africa's Negotlated Settlement (Doreen Atkinson \& Stephen Friedman eds., 1994).

24 See Center for Human Rights, University of Pretoria, Introduction to Socio-Economic Rights in the South African Constitution, http://www.chr.up.acza/centre_projects/socio/compilation 1 part1. 
This also was not surprising. Although the national liberation movements had largely been committed to policies of economic redistribution, by the 1990 s the international consensus had shifted to one in which human rights were embodied not by redistribution of material resources in the world, but in legal texts such as bills of rights. Indeed Upendra Baxi, the Indian legal scholar, has articulated how this text-based version of human rights discourse was seeking to "supplant all other ethical discourses." ${ }^{25}$ In a similar vein, Boa de Sousa Santos, the Portuguese scholar, has noted how human rights has become the lingua franca of "progressive politics," providing an "emancipatory script" for those seeking redress from injustice. ${ }^{26}$

The South African Constitution and its expansive Bill of Rights reflects this paradigmatic shift in the characterization and articulation of human rights norms. In addition, the South African Constitution represents a vindication of decades of human rights activism, not just because of its expressed human rights commitment in the Bill of Rights, but also because the Constitution made South Africa, formally at least, a version of the penultimate human rights state. ${ }^{27} \mathrm{As}$ Makau wa Mutua, the Kenyan human rights scholar notes:

The construction of the post-apartheid state represents the first deliberate and calculated effort in history to craft a human rights state - a polity that is primarily animated by human rights norms. South Africa was the first state to be reborn after the universal acceptance (at least rhetorically) of human rights ideals by states of all the major cultural and political traditions. ${ }^{28}$

If one looks at the trajectory of human rights discourse during the decades following the passage of the Universal Declaration of Human Rights, including those shameful periods when human rights became hostage to cold war politics, the South Africa embrace of human rights principles provided a welcoming ray of hope.

html; see also Nicholas Haysom, Giving Effect to Socio-Economic Rights, Community Law Center, Socio-Economic Rights Project, Vol. 1 No. 4 (March 1999) at 1, http://www.communitylawcentre .org.za/Projects/Socio-Economic-Rights/esr-review (follow "Download this edition in pdf format" hyperlink).

${ }^{25}$ Upendra Baxi, Voices of Suffering and the Future of Human Right, 8 TRansnat'L J. OF L. \& Contemp. Probs. 125, 147 (1998).

26 Boaventura de Sousa Santos, Toward a Multicultural Conception of Human Rights, I ZEITsCHRIFT Fur Rechtssoziologie 1 (1997) (F.R.G.).

${ }^{27}$ Makau wa Mutua, Hope and Despair for a New South Africa: The Limits of Rights Discourse, 10 Harv, Hum. RTs. L. J. 63 (1997).

28 Id. at 65. 


\section{The South African Constitution}

The South African Constitution reflects not only the influence of the global human rights struggle, but is in many ways a by-product of that struggle. The Constitution embraces international law in several ways. ${ }^{29}$ First, the Constitution's comprehensive Bill of Rights ${ }^{30}$ is drawn entirely from several human rights instruments, including the Universal Declaration of Human Rights, the International Covenant on Civil and Political Rights ${ }^{31}$ and the International Covenant on Economic, Social and Cultural rights. ${ }^{32}$ The Bill of Rights is expansive, incorporating a range of civil and political rights, as well as economic, social and cultural rights. ${ }^{33}$ Implicit in this comprehensive embrace of rights is the notion that rights are interdependent, and that civil and political rights reinforce social and economic rights, and vice-versa. ${ }^{34}$ This recognition implicitly eschews a bifurcated or hierarchical approach to rights, in favor of one that views all rights as integral to the pursuance of dignity and equity. This vision is further bolstered by the provisions of Article 38 in the Bill of Rights, which explicitly renders all rights justiciable. ${ }^{35}$

The second way that the Constitution incorporates international law is that Article 39 of the Constitution specifically directs the South African courts to consider international law in their deliberations. ${ }^{36}$ Finally, Article 232 of the Constitution provides for the direct incorporation of international law into the

29 For a thoughtful analysis of the engagement of the South African Constitution with international law, see John Dugard, International Law and the 'Final' Constitution, 11 SAJHR 241 (1995).

30 S. Afr Const. 1996, The Bill of Rights, ch. 2, available at http://www.info.gov.za/documents/ constitution/index.htm.

311966 U.S.T. 521, 999 U.N.T.S. 171 (entered into force Mar. 23, 1976 ).

${ }^{32}$ G.A. Res. 2200A (XXI), 21 st Sess., Supp. No. 16, at 49, U.N. Doc. A/6316 (1966), 993 U.N.T.S. 3 (entered into force Jan. 3, 1976).

${ }^{3}$ See S. Apr. Const. 1996, supra note 30. For a thoughtful discussion on the incorporation of social and economic rights in the S. ApR Consr. 1996, see Sandra Liebenberg, The International Covenant on Economic, Social and Cultural Rights and its Implications for South Africa, 11 SAJHR 359 (1995).

34 See Neil MacCormick, Legal Rights and Soctal Democracy: Essays in Legal and Political Philosophy 42 (1982).

35 See Pierre De Vos, Pious Wishes or Directly Enforceable Human Rights? Social and Economic Rights in South Africa's 1996 Constitution, 13 SAJHR 67 (1997); see also Penelope E. Andrews, The South African Bill of Rights: Lessons for Australia, in Comparattve Perspectives on Bilis of Rights (Christine Debono \& Tania Colwell eds., 2004).

36 S. Apr Const. 1996, supra note 30, $\$ 39$ provides that, " [w] hen considering the Bill of Rights, a court ... must consider international law .... \$233 provides that, "when interpreting any legislation, every court must prefer any reasonable interpretation of the legislation that is consistent with international law over any alternative interpretation that is inconsistent with international law." (emphasis added). 
South African legal system. ${ }^{37}$ South Africa is party to several international human rights instruments that range from the elimination of racial discrimination, slavery and genocide, the suppression of human trafficking, the rights of women, children and refugees. ${ }^{38}$ Article $37-4(\mathrm{~b})(1)$ of the Constitution specifically provides that emergency legislation enacted may derogate from the Bill of Rights only to the extent that it is consistent with South Africa's obligations under international law. ${ }^{39}$

In its founding provisions, the Constitution outlines the human rights principles on which the new democratic state is promised. These include:

- Human dignity, the achievement of equality and the advancement of human rights and freedoms

- Non-racialism and non-sexism

- Supremacy of the constitution and the rule of law

- Universal adult suffrage, a national common voter's roll, regular elections and a multi-party system of democratic government, to ensure accountability responsiveness and openness. ${ }^{40}$

The Constitution, with its expansive Bill of Rights, has been universally heralded for the range of protections it affords, and the purposive manner in which it affords such protections. ${ }^{41}$ For example, the Bill of Rights outlaws both direct and indirect discrimination, an approach that reflects a deep appreciation of the invidious manner in which discrimination is manifest, both consciously and unconsciously. ${ }^{42}$ The Bill of Rights contains a general commitment to equality before the law and equal protection under the law, and provides several grounds

${ }^{37}$ Id. $\$ 232$ specifically provides that customary international law is the law of South Africa unless such law contradicts the Constitution or an Act of Parliament. $\$ 231$ outlines the conditions under which international agreements become part of South African law. $\$ 198$ provides that the Security services must act "in accordance with ... customary international law and international agreements ...."

38 See Human Rights \& Documentation Centre, Gender Issues and Democracy in Southern Africa, http://www.hrdc. unam.na/rsa_hr.htm.

39 S. Afr. CoNsT. 1996, supra note $30, \$ 37(4)$ (b)(i).

40 Id. $\$ \$ 1-6$.

${ }^{41}$ See Karl Klare, Legal Culture and Transformative Constitutionalism, 14 SAJHR 146 (1998); see also Craig Scott \& Philip Alston, Adjudicating Constitutional Priorities in a Transnational Context: A Comment on Soobramoney's Legacy and Grootboom's Promise, 16 SAJHR 206 (2000).

42 S. Afr. Const. 1996, supra note 30, $\$ 9$, para. 4 provides that, “[n]o person may discriminate directly or indirectly against any one on one or more grounds." For an interesting discussion on the subliminal manner in which, for example, racism is often manifest, see Charles Lawrence, The Id. the Ego and Equal Protection: Reckoning with Unconscious Racim, 39 STAN. L. REV. 317 (1987). 
on which the states may not unfairly discriminate, including race, color, gender, religion, ethnicity, age, disability and sexual orientation. ${ }^{43}$ In addition, the Bill of Rights recognizes that sometimes these grounds of discrimination overlap, and therefore incorporates protections against the intersectionality of different grounds of discrimination. ${ }^{44}$ The Bill of Rights protects the human rights of women, and in particular seeks to respond to the phenomenon of violence against women in several ways, including the outlawing of violence "from either public or private sources." ${ }^{45}$ Drawing from the African concept of ubuntu, ${ }^{46}$ the Bill of Rights provides for the right to have one's dignity respected and protected. ${ }^{47}$

In particular, the following civil and political rights are protected: the right to life, ${ }^{48}$ freedom and security of the person, ${ }^{49}$ the right against slavery, servitude and forced labor, ${ }^{50}$ the right to privacy, freedom of religion, belief, expression, opinion, assembly, movement, association ${ }^{51}$ and a range of property ${ }^{52}$ and labor rights. ${ }^{53}$ In addition, the Constitution also incorporates the right of access to information, ${ }^{54}$ to due process, the right to a fair trial and access to the courts. ${ }^{55}$ All of these rights derive from those incorporated in the Universal Declaration of Human Rights

${ }^{43}$ S. Afr. Const. 1996, supra note $30, \$ 9$, para. 3 provides that "[ $\left.\mathrm{r}\right]$ he state may not unfairly discriminate directly or indirectly against anyone on one or more grounds, including race, gender, sex, pregnancy, marital status, ethnic or social origin, colour, sexual orientation, age, disability, religion, conscience, belief, culture, language and birth."

4 Id. $\$ 9$, para. 5 provides that, "[d] iscrimination on one or more grounds ... is unfair unless it is established that the discrimination is fair." (emphasis added). This concept of intersectionality has been analyzed in some detail by critical race scholars. See e.g., Kimberley Crenshaw, Mapping the Margins: Intersectionality, Identity Politics and Violence Against Women of Color, in Inenritues 175 (Linda Alcoff \& Eduardo Mendieta eds., 2002); see also Angela Harris, Race and Essentialism in Feminist Legal Theory, 42 StAN. L. Rev. 581 (1991).

45 Id. $\$ 12(1)$ (c) provides that, "[e]veryone has the right to security and freedom of the person which includes the right ... to be free from all forms of violence from either public or private sources ...."

46 For an explanation of ubuntu, see Justice Yvonne Mokgoro, Ubuntu and the Law in South Africa at http://epfecoport. org/appendix3.html.

4) S. Afr Const. 1996, supra note 30, provides that, "[e]veryone has inherent dignity and the right to have their dignity respected and protected."

48 Id. $\$ 11$.

49 Id. $\$ 11-12$.

so Id. $\$ 13$.

51 Id. $\$ 15-18$.

52. Id. $\$ 25$.

53 Id. $\$ 22-23$.

54 Id. $\$ 32$.

55 Id. $\$ 33-35$. 
and the International Covenant on Civil and Political Rights. In a series of cases, the South African Constitutional Court has interpreted the relevant constitutional right in light of the international human rights document from which it derives, thereby interpreting such international document in the South African context. ${ }^{56}$ For example, in $S v$ Baloyi, ${ }^{57}$ in balancing the procedural rights of the accused, on the one hand, and the need to stem private violence against women, on the other, the Constitutional Court interpreted South Africa's obligations under the United Nations Declaration on Violence Against Women ${ }^{58}$ and Convention on the Elimination of All Forms of Discrimination Against Women, ${ }^{59}$ to reject a challenge to the constitutionality of domestic violence legislation. ${ }^{60}$

In addition to these so-called first-generation rights, the Bill of Rights incorporates a range of socio-economic rights, including the right to an anvironment that is beneficial, ${ }^{61}$ the right to have access to housing, ${ }^{62}$ health care,${ }^{63}$ food, water, social security, ${ }^{64}$ education. ${ }^{65}$ Theses social and economic rights are not available on demand, as first-generation rights are. That said, the state must provide these rights "within its available resources". ${ }^{66}$ Drawing from the Convention on the Rights of the Child, ${ }^{67}$ the Bill of Rights provides for a series of children's rights, protecting them from abuse, but also providing for a host of socio-economic rights that they are entitled to, including the right to basic nutrition, health care, shelter and social services. ${ }^{68}$

56 For example, in the first case heard by the Constitutional Court that involved the abolition of the death penalty, the Court went through an extended analysis of the International Covenant on Civil and Political Rights. See S v Makwanyane 1995 (3) SA 391 (CC) (S. Afr.).

572000 (2) SA 674 (CC) (S. Afr.).

${ }^{58}$ G.A. Res. 48/104, U.N. GAOR, 48th Sess., Supp. No. 49, U.N. Doc. A/RES/48/49 (Dec. 20, 1993).

39 Adopted and opened for signature, ratification and accession by G.A. Res. 34/180, U.N. GAOR, 34th Sess., Supp. No. 46, U.N. Doc. A/34/46 (Dec. 18, 1979) (entered into force Sept. 3, 1981).

${ }^{60} \mathrm{~S}$ v Baloyi, supra note 57 , at para. 13.

${ }^{61}$ S. Afr. Const. 1996, supra note $30, \$ 24$.

${ }^{62}$ Id. $\$ 26$.

${ }^{63}$ Id. $\$ 27$.

${ }^{64}$ Id.

${ }^{65}$ Id. $\$ 29$.

${ }^{66}$ Id.

${ }^{67}$ Adopted and opened for signature, ratification and accession by G.A. Res. 44/25, U.N. GAOR, 4th Sess., Supp. No. 49, U.N. Doc. A/RES/44/25 (Nov. 20, 1989) (entered into force Sept. 2, 1990).

${ }^{68}$ S. Afr. Const. 1996, supra note 30, $\$ 28$. 
Under South African law, several bodies are mandated to pursue the human rights embodied in the Constitution, including: the Public Protector, ${ }^{69}$ the Human Rights Commission; ${ }^{70}$ the Commission for Gender Equality; ${ }^{71}$ the Electoral Commission $^{72}$ and the Commission for the Promotion and Protection of the Rights of Cultural, Religious and Linguistic Communities. ${ }^{73}$ Of these bodies, the Human Rights Commission and the Gender Commission are central to the implementation and enforcement of the human rights embodied in the Bill of Rights. The establishment of two separate bodies with ostensibly similar functions, albeit the one focusing only on gender, created controversy. Many women advocates were of the opinion that a structure such as a Gender Commission would marginalize and even trivialize women's equality. ${ }^{74}$ They believed that the pursuit of women's rights should be incorporated into a structure that promotes rights for all. ${ }^{75}$ Opponents argue that only a separate body can deal comprehensively with gender equality concerns and develop a sustained and systemic approach to the eradication of sexism and patriarchy. ${ }^{76}$ In the final analysis, the latter sentiments held sway and a separate body, the Gender Commission, was established. In addition to the constitutionally mandated bodies, several human rights bodies, including the office of the Status of Women, of the Office on the Rights of the Child and the Office on the Rights of People with Disabilities, have been set up in the office of the President.

69 Id. $\$ 182$, empowering the Public Protector to "investigate any conduct in state affairs, or in the public administration, or in any sphere of government that is alleged or suspected to be improper or to result in any impropriety or prejudice ...."

70 The Human Rights Commission is mandated to: "promote respect for human rights and a culture of human rights; promote the protection, development and attainment of human rights; monitor and assess the observance of human rights" in South Africa. Id. $\$ 184$.

71 The Commission for Gender Equality is empowered to "promote respect for gender equality, and the protection, development and attainment of gender equality ... ." Id. $\$ 187$.

72 The task of the Electoral Commission is to "manage elections" and to "ensure that they are free and fair." Id. $\$ 190$.

73 As its name suggests, the Commission is mandated to "promote respect for the rights of cultural, religious and linguistic communities; to promote and develop peace, friendship, humanity, tolerance and national unity amongst cultural, religious and linguistic communities, on the basis of equality, non-discrimination and free association ...." Id. $\$ 185$.

74 See Catherine Albertyn, National Machinery for Ensuring Gender Equality, in THe Constrtution op South Africa From a Gender Perspective 17 (Sandra Liebenberg ed., 1995); see also Catherine Albertyn, Women and the Transition to Democracy in South Africa, in GENDER AND the South African Legal Order 39 (Christina Murray ed. 1994).

75 For an interesting discussion of this debate, see Albertyn, National Machinery for Ensuring Gender Equality, supra note 74, at 16-17.

76 See Penelope E. Andrews, Striking the Rock: Confronting Gender Equality in South Africa, in 3 Mich. J. RACE \& L. 307, 330-331 (1998). 


\section{The Jurisprudence of the Constitutional Court and International Law}

The Constitutional Court of South Africa has adopted a bold vision of human rights in its jurisprudence. Since its inception in 1995, the Constitutional Court has heard several cases that directly implicate the international human rights agenda embodied in the Constitution. In this endeavor the Constitutional Court has incorporated international human rights law in its interpretation of the Bill of Rights, and by doing so has spawned an international human rights jurisprudence that continues to be cited in many jurisdictions. ${ }^{77}$ Indeed, the international human rights legal literature constantly references the transformative human rights jurisprudence of the South African Constitutional Court. ${ }^{78}$

The Court's docket has included international legal issues in several landmark cases. The first case that the Court heard in 1995, Sv Makwanyane, concerned the constitutionality of the death penalty ${ }^{79}$ The Court, invoking the right to life and right to dignity found in the Bill of Rights, the International Covenant on Civil and Political Rights, and other human rights instruments, struck down the death penalty as unconstitutional. ${ }^{80}$ In this case, the Constitutional Court demonstrated its central role in the democratic transformation process in South Africa. The case, littered with references to international law, including the International Covenant on Civil and Political Rights, ${ }^{81}$ and foreign law, including the United States Supreme Court decision in Furman v. Georgi $a^{82}$ has demonstrated that its approach was jurisprudentially expansive, as opposed to a more self-referential approach taken by the United States Supreme Court, for example.

In a series of cases, the Court examined the question of equality, the paramount principle in the Bill of Rights and in international law. Exploring a range of factual situations, including those involving the rights of HIV positive persons not to be

77 See Jennifer L. Hube, Legal Representation for Indigent Criminal Defendants, 5 Duke J. Coмr. \& INT'L L. 425 (1995) (citing Sv Baloyi); Alan Clarke, Terrorism, Extradition and the Death Penalty, 29 WM. Mrtchell L. Rev. 803 (2003); Martha L. Salomon, AIDS is Risky Business: Examining the Effects of the AIDS Crisis on Publicly Traded Companies in South Africa and the Implications for Both South African and U.S. Investors, 37 VAND. J. TransNat'L L. 1473 (2004).

78 See, eg., Klare, supra note 41; see also, Dennis Davis, Democracy and Deliberation (1999).

79 S v Makwanyane, supra note 56.

80 Id., para. 151.

81 Adopted and opened for signature, ratification and accession by G.A. Res. 2200A (XXI), U.N. GAOR, 21 st Sess., Supp. No. 16, U.N. Doc. A/6319 (Dec. 16, 1966) (entered into force Mar. 23 1976)(mentioned at para. 62).

82408 U.S. 238 (1972) (mentioned at para. 40). 
discriminated against in their employment ${ }^{83}$ the rights of permanent residents not to be treated unfairly in comparison to citizens in the workplace, ${ }^{84}$ the rights of homosexuals to be engage in consenting sexual conduct ${ }^{85}$ and the rights of African girls and women not to be discriminated against under indigenous customary law, ${ }^{86}$ the Court has formulated a substantive vision of equality. ${ }^{87}$ In doing so the Court has moved from a mere formal approach to one that recognizes the peculiar realities of South Africa and has attempted to contextualize equality within the South African context. ${ }^{88}$ The court has accomplished this by embracing international human rights principles, whilst at the same time recognizing the peculiar context of South Africa's history of inequality, and the need to develop a comprehensive indigenous version of equality. ${ }^{89}$

This was demonstrated in one of the earliest cases that analyzed the right to equality, in which the court was confronted with a challenge by a convicted male prisoner to a Presidential Pardon. ${ }^{90}$ The challenged Presidential Pardon, issued by President Nelson Mandela after South Africa's first democratic election, had pardoned certain categories of prisoners, including women in prison who had children under the age of twelve. ${ }^{91}$ The complainant challenged the Presidential Pardon on the basis that it violated his constitutional rights to equality and that

${ }^{83}$ Hoffman y S. Afr. Airways 2001 (1) SA 1 (CC) (S. Afr.) (unanimously holding that the airline could not exclude an otherwise qualified asymptomatic HIV-positive job applicant and rejecting the airline's economic interests as compelling when balanced against the infringement of the applicant's right to equality).

${ }^{84}$ Larbi-Odam v Member of the Exec. Council For Educ. (Nw Province) 1998 (1) SA 745 (CC) (S. Afr.) (unanimously invalidating a regulation that prohibited foreign citizens from permanent employment as teachers in state schools).

${ }^{85}$ Nat'l Coal. for Gay and Lesbian Equal. v Minister of Justice 1999 (1) SA 1 (CC) (S. Afr.) (declaring unconstitutional the common law offense of sodomy and applicable criminal laws on sodomy).

${ }^{86}$ BHE v Mag. (1) SA 563 (CC) (S. Afr.) (finding the inheritance rules for black estates found in the Black Administration Act and the system of male primogeniture in African customary law inconsistent with the Constitution).

${ }^{87}$ See Catherine Albertyn \& Janet Kentridge, Introducing the Right to Equality in the Interim Constitution, 10 SAJHR 149 (1994).

${ }_{88}$ See Pierre de Vos, Grootboom, the Right of Access to Housing and Substantive Equality as Contextual Fairness, 17 SAJHR 258 (2001).

89 A classic example was AZAPO v Pres. of the Republic of S. Afr., supra note 3, in which the Constitutional Court struck down a challenge to the amnesty provisions of the Truth and Reconciliation Commission. Reçognizing the important international human rights principles implicated in the amnesty provisions, the Court nonetheless rejected the international law approach, in favor of the principles agreed to during South Africa's negotiations towards a constitutional democracy.

90 President of the Republic of S. Afr. v Hugo 1997 (4) SA 1 (CC) (S. Afr.).

91 Presidential Act No. 17 of 1994. 
it discriminated against him on the basis of sex. The Court, in its judgment, engaged in a comprehensive discussion of equality.

Applying the test outlined in the Constitution, the Court found that the discrimination was unfair. ${ }^{92}$ But the Court also found that the discrimination could be justified because of the benefits derived from the pardon, including those that accrued to children and their mothers; ${ }^{93}$ in the Court's opinion, the latter was clearly the most disadvantaged group in South African society. Although acknowledging that its findings may reinforce a stereotype about women, child caring and child rearing, the Court recognized that mothers are the primary caregivers of children. The Court saw its approach as pragmatic: one that placed the issue squarely within the reality of the South African context. Finding the discrimination valid, the Court stated that because women have historically been discriminated against, the adoption of this contextual approach would benefit women, and not perpetuate a disadvantage. ${ }^{94} \mathrm{~A}$ literal reading of the Court's judgment suggests a contradiction of one of the principles incorporated in The Convention on the Elimination of All Forms of Discrimination against Women (CEDAW), namely, that state parties need:

To ensure that family education includes a proper understanding of maternity as a social function and the recognition of the common responsibility of men and women in the upbringing and development of their children, it being understood that the interest of therchildren is the primordial consideration in all cases. ${ }^{95}$

The dissent forcefully challenged the pragmatic approach taken by the majority and the stereotypes that the majority appeared to perpetuate, stating very clearly that the Constitution was meant to be transformative. ${ }^{96}$ But the majority judgment, despite the dissent, reflected that the judges interpreted the Constitution as not just providing a formal flavor to equality. They grappled with both the

${ }_{22}$ The Constitution articulates a two-part test for finding discrimination. First, if discrimination is alleged and found on any of the listed grounds, such as race, gender, marital status or nationality, that finding creates a presumption of unfairness. The person against whom the allegation of discrimination is made must then rebut the presumption of unfairness by showing the validity of the action. See S. Apr Const. 1996, supra note $30, \$ 9$, paras. $1 \& 5$.

${ }_{93}$ President of the Republic of S. Afr. v Hugo, supra note 90, paras. 39 \& 47.

94 "In this case, mothers have been afforded an advantage on the basis of a proposition that is generally speaking true. There is no doubt that the goal of equality entrenched in our constitution were better served if the responsibilities for child rearing were more fairly shared between mothers and fathers. The simple fact of the matter is that at present they are not. For the moment then, and for some time to come, mothers are going to carry greater burdens than fathers in the rearing of children. We cannot ignore this crucial fact in considering the impact of discrimination in this case." Id.s (judgment of Justice O'Regan at 113).

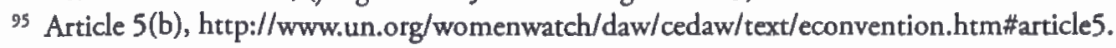

${ }_{96}$ President of the Republic of S. Afr. v Hugo, supra note 90, at 63 (judgment of Justice Kriegler). 
contemporary realities of formal equality in South Africa, and the deeply entrenched patterns of gender equality, one of the legacies of apartheid. As so eloquently stated by Justice O'Regan:

To determine whether the discrimination is unfair it is necessary to recognize that although the long-term goal of our constitutional order is equal treatment, insisting upon equal treatment in circumstances of established inequality may well result in the entrenchment of that inequality.

In its approach to curbing violence against women, several decisions of the Court have been particularly compelling. In these decisions, the Court utilized the imperatives in the Bill of Rights, as well as those found in international instruments such as the International Convention on the Elimination of All Forms of Discrimination Against Women ${ }^{98}$ and the Vienna Declaration on Violence Against Women. ${ }^{99}$ The Court adopted a purposive approach, outlining very clearly in its pronouncements the need to eradicate the ubiquitous problem of violence against women in South Africa, and has applied this approach in both the public as well as the private law arena. In $S v$ Baloyi, a challenge to South Africa's domestic violence legislation, the Court has articulated clearly that while it will protect the procedural rights of those accused of domestic violence, it will ensure that the constitutional mandate that prohibits all forms of violence, including violence committed in the home, be clearly pursued to protect women. ${ }^{100}$ Justice Albie Sachs, writing an impressive judgment for the majority noted:

All crime has harsh effects on society. What distinguishes domestic violence is its hidden repetitive character and its immeasurable ripple effects on our society and in particular, on family life. It cuts across class, race, culture and geography, and is all the more pernicious because it is so often concealed and so frequently goes unpunished. ${ }^{101}$

The Court, reinforcing its commitment to stemming public violence against women, has held the police and other government authorities liable where they negligently failed to protect women from violence committed by third parties. ${ }^{102}$ By doing so the Court has infused into the common law, in this case the law of

97 Id. at 112 (judgment of Justice O'Regan).

${ }^{98}$ Adopted and opened for signature, ratification and accession by G. A. Res. 34/180 U.N. GAOR, $34^{\text {th }}$ Sess., Supp. No. 46, U.N. Doc. A/34/46 (Dec. 18, 1979) (entered into force Sept. 3, 1981).

99 Vienna Declaration and Programme of Action, World Conference on Human Rights, U.N. Doc. A/CONF. 157/23 July 12, 1993.

$100 \mathrm{~S}$ v Baloyi, supra note 57.

101 Id. at 11 .

102 Alix Jean Carmichele v Minister of Safety \& Sec. 2001 (4) SA 938 (CC) (S. Afr.). 
torts, the principles embodied in the Constitution. ${ }^{103}$ In this case the police and prosecutors had recommended the release without bail of a man awaiting trial on a charge of attempted rape, and who later brutally attacked another woman. The Court held that the common law could be sufficiently developed to impose on police and prosecutors a legal duty to protect such third parties, in light of the Constitution and international law's prohibition on gender discrimination and the right to dignity, freedom and security of women. ${ }^{104}$

The Court has struck an impressive balance between the competing rights of privacy and state regulation, ${ }^{105}$ and religious rights and equality, ${ }^{106}$ appreciating the context of the lived realities and steadfastly held beliefs of individuals and groups, and the need to create a society predicated on equality and dignity. In the same vein the Court has tried to strike a healthy accord between the rights of criminals in a very violent society, such as South Africa, and the rights of individuals to security of the person. ${ }^{107}$

By far the most impressive accomplishments of the Court has been its slow evolution of a socio-rights jurisprudence that attempts to redress the appalling economic conditions within which a large number of South Africans still find themselves. Mindful of the doctrine of separation of powers and not wishing to overcome the prerogative of Parliament, the Court has nonetheless attempted to ensure that the

${ }^{103}$ S. Apr. Consr. 1996, supra note 30, $\$ 39$, para. 2 , provides that, "[w] hen interpreting any legislation and when developing the common law ... every court, tribunal or forum must promote the spirit, purport and objects of the Bill of Rights." (emphasis added).

${ }^{104}$ Alix Jean Carmichele v Minister of Safety \& Sec., supra note 102, para. 33.

${ }^{105}$ See Nat'l Coal. for Gay and Lesbian Equal. v Minister of Justice, supra note 85. See also De Reuck v Dir. Pub. Prosec. (W.L.D.) 2004 (1) SA 406 (CC) (S. Afr.) (finding a law prohibiting the importation and possession of child pornography to be a reasonable interference with privacy and not overbroad, given an objective definition of child pornography whose primary element is the stimulation of erotic rather than aesthetic feeling, and the presence of a good cause exemption for individuals conducting research on child pornography).

${ }^{106}$ See Christian Educ. S. Afr. v Minister of Educ. (4) SA 757 (CC) (S. Afr.) (recognizing that corporal punishment in Christian schools may constitute an important part of religious identity and ethos, the Court nonetheless upheld a law of general applicability prohibiting corporal punishment in schools given the compelling public interest in protecting students from physical and emotional abuse and what it viewed as a limited interference in the ability of parents to otherwise follow their religious conscience). See also Prince $v$ Pres. of the Law Society of the Cape of Good Hope 2002 (2) SA 794 (CC) (S. Afr.) (finding the right of the Rastafarian religion to use cannabis as part of the teligious practice outweighed by the state's interest in enforcing drug legislation intended to curb its use).

${ }^{107}$ See Alix Jean Carmichele v Minister of Safety \& Sec., supra note 102. See also K v Minister of Safety \& Sec. 2005 (9) BCLR 835 (CC) (S. Afr.). 
government addresses the needs of the poor in the country. In The Government of the Republic of South Africa, et al. $v$ Grootboom and Others, ${ }^{108}$ a case widely regarded as international test case on the enforceability of social and economic rights, the Court outlined in great detail the obligation of the government to provide housing for those desperate for shelter. The case concerned an application for temporary shelter brought by a group of people, including a number of children, who were without shelter following their brutal eviction from private land on which they were squatting. The conditions under which the community lived were deplorable. They had access to water through one tap that served hundreds of people, and no sanitation facilities. The Court affirmed that the government had a duty in terms of Section 26 of the Constitution (the right to adequate housing) ${ }^{109}$ to adopt reasonable policy, legislative and budgetary measures to provide relief for people who have no access to land, no roof over their heads, and who are living in intolerable conditions. The judgment also dealt in details with the implications of the children's socio-economic rights enshrined in Section $28 .{ }^{110}$

The Court dealt in some detail with the provisions in the International Covenant on Economic, Social and Cultural Rights (ICESCR), and in particular the articles that outline the substantive nature of the rights incorporated in the Covenant as well as the obligations of states to take reasonable steps to realize those rights. ${ }^{111}$ Elaborating in the obligation in both ICESR and the South African Constitution, the Court determined that the government had the duty to respect, protect, promote and fulfill these rights. ${ }^{12}$ In addition, the Court examined the comments of the United Nations Committee on Economic, Social and Cultural Rights (ECOSOC), and particularly the comment that socio-economic rights contain a minimum core. ${ }^{113}$ The Court, pointing out that ICESCR

${ }^{108} 2001$ (1) SA 46 (CC) (S. Afr.).

${ }^{109}$ S. Afr Const. 1996, supra note $30, \$ 26$ provides that: "(1) Everyone has the right to have access to adequate housing. (2) The state must take reasonable legislative and other measures, within its available resources, to achieve the progressive realization of this right. (3) No one may be evicted from their home, or have their home demolished ...."

${ }^{110} I d$. $\$ 28$ covers a range of rights to which children are entitled, including basic nutrition, shelter, basic health care and social services.

${ }^{14}$ In particular, the Court analyzed $\$ 11.1$ of the Covenant, which provides that the "[t]he State parties to the present Covenant recognize the right of everyone to an adequate standard of living for himself and his family, including adequate food, clothing and housing, ... The State parties will take appropriate steps to ensure the realization of this right ...." $\$ 2.1$ of the Covenant provides that, "[e]ach State party to the present Covenant undertakes to take steps, ... to the maximum of its available resources, with a view to achieving progressively the full realization of the rights recognized in the present Covenant by all appropriate means."

${ }^{112}$ S. Afr Const. 1996, supra note 30, $\$ 7$, para. 2.

${ }^{113}$ Gov't of Republic of S. Afr. v. Grootboom 2000 (11) BCLR 1169 (CC) (S. Afr.). 
provides for the right to housing, whereas the South African Constitution provides a right of access to housing, rejected the "minimum core" approach and instead opted for one that imposed on the South African the requirement of reasonableness in its housing policy. ${ }^{114}$ Although the Court engaged in an extensive analysis of ICESR and the obligations as articulated by ECOSOC, the Court concluded that the concept "minimum "core" did not create sufficient flexibility and appreciation of the peculiar conditions of South Africa. ${ }^{115}$

In line with its requirement of reasonableness, the Court has also mandated the government, in compliance with the right to health as delineated in the Bill of Rights, ${ }^{116}$ as well as the rights of children, ${ }^{117}$ to provide anti-retroviral drugs to HIV-positive pregnant women at public hospitals throughout South Africa. ${ }^{118}$ The Court has also protected those who are not South African citizens from violations of their constitutional socio-economic rights, holding that a scheme that excluded permanent residents from social assistance was discriminatory and unfair. ${ }^{119}$

The above analysis demonstrates the manner in which the Constitutional Court has embraced international legal principles, and particularly with regard to its human rights, equality and socio-economic rights jurisprudence. And even though the Court may not have adopted the methodological approaches of the relevant international human rights body, such as its diversion from that taken by the United Nations Committee on Economic, Social and Cultural Rights on the question of the minimum core content of a right, the Court has for the most part embraced both the substance and the spirit of the various international legal documents.

In some cases, however, the Court has found that resort to international law was irrelevant or marginal to the determination of the constitutionality or otherwise of a statute or other form of governmental action. ${ }^{120}$ This was essentially the approach

114 Id. paras. 27-29.

${ }^{115}$ Id. para. 33.

${ }^{116}$ S. Apr Const. 1996, supra note 30, $\$ 27$ provides that everyone "has the right to have access to health care services, including reproductive health care" and that the "state must take reasonable legislative and other measures, within its available resources, to achieve the progressive realization of all of these rights...."

${ }^{117}$ Gov't of Republic of S. Afr. v. Grootboom, supra note 113.

${ }^{118}$ Minister of Health v. Treatment Action Campaign 2002 (2) SA 721 (CC) (S, Afr.) (finding unreasonable the government's refusal to make widely available the anti-retroviral drug nevirapine until it had further tested the safety and efficacy of the drug and its failure to set out a time frame for a national program to reduce mother-to-child transmission of HIV).

${ }^{119}$ Khosa v. Minister Soc. Dev.; Mahlaule v. Minister Soc. Dev. 2004 (6) SA 505 (CC) (S. Afr.) (finding in the scheme a violation of the right to equality as well as finding that the Constitution vests a right to social security in "everyone").

${ }^{120}$ For a thoughtful analysis of the way in which the Constitutional Court "reads in and out" international law, see Catherine Adcock Admay, Constitutional Comity: Mediating the Rule of Law Divide, 26 N.C. J. Int'l \& Com. Reg. 723 (2001). 
taken by the Court in a highly publicized case challenging both the constitutionality of the Truth and Reconciliation Commission (TRC), as well as its putative violation of international law, ${ }^{121}$ in particular, the international law requirement that those who commit gross violations of human rights be punished as mandated by four Geneva Conventions. ${ }^{122}$ In this case the Court was faced by a challenge from family members of those tortured and killed by the South African government, that the empowering statute of the TRC, ${ }^{123}$ and especially its amnesty committee, ${ }^{124}$ was both unconstitutional and in violation of international law. ${ }^{125}$

The petitioners claimed that the well-established international legal principle, that the perpetrator of gross violations of human rights has to compensate the victim for the injuries suffered, are clearly violated by the amnesty provisions of the T.R.C. ${ }^{126}$ Regarding the constitutionality of the TRC statute, the petitioners claimed that the amnesty provision immunized perpetrators of gross violations of human rights from criminal and civil liability. This immunity applies as well to those who might be held vicariously liable for the perpetrators' actions, including state authorities. ${ }^{127}$ These amnesty provisions clearly violated the Constitution, which provided that:

Every person shall have the right to have justiciable disputes settled by a court of law, or where appropriate, another independent or impartial forum. ${ }^{128}$

The petitioners argued that the amnesty committee was neither a "court of law" nor an "independent or impartial forum", and that the amnesty committee was not empowered to settle "justiciable disputes." 229 The petitioners relied on the well established international law principle that those who are victims of gross

${ }^{121}$ AZAPO v Pres, of the Republic of S. Afr., supra note 3.

${ }^{122}$ Article 49 of the first Geneva Convention For the Amelioration of the Condition of the Wounded and Sick in Armed Forces in the Field; Article 50 of the second Geneva Convention for the Amelioration of the Wounded, Sick and Shipwrecked members of Armed Forces at Sea; Article 29 of the Third Geneva Convention relative to the Treatment of Prisoners of War; and Article 46 of the fourth Geneva Convention relative to the Protection of Civilian Persons during time of War. See Id., para. 25.

${ }^{123}$ Promotion of National Unity and Reconciliation Act No. 34 of 1995.

${ }^{124}$ In terms of the statute, amnesty is to be granted to all "persons who make full disclosure of all the relevant facts relating to acts associated with a political objective. ..." Id., $\$ 3(1)$ (b).

${ }^{125}$ AZAPO v Pres. of the Republic of S. Afr., supra note 3, para. 25.

${ }^{126} \mathrm{Id}$.

${ }^{127}$ These amnesty provisions are contained in $\$ 20$ of the Promotion of National Unity and Reconciliation Act, supra note 123.

${ }^{128}$ S. Afr. Const. 1996, supra note 30, \$22.

${ }^{129}$ AZAPO v Pres. of the Republic of S. Afr., supra note 3, para. 8. 
human rights violations have the right of access to a legal forum to have their claims considered and adjudicated. ${ }^{130}$

In a detailed judgment, the Court in effect skirted the relevant international legal principles by focusing only on the constitutionality of the TRC. Judge Mahomed, writing for the majority, found that the TRC had in fact passed constitutional muster. Even though the Constitution clearly provided the right to have "justiciable disputes settled by a court of law," the same section empowers the South African government to provide amnesties for past wrongs where it is deemed appropriate. ${ }^{131}$

The holding in this case generated some controversy, as many commentators were of the opinion that the Court gave short shrift to international law by refusing to engage with the relevant issues in its deliberations. ${ }^{132}$ It is arguable that the Court in fact followed the contextual approach it adopted in other cases, and that the constitutional principles provided the Court with a sufficient basis on which to dispose of the challenge to the TRC. The Court has also noted that although the Constitution mandates the Court to consider international law, it does not have to adopt such law.

\section{E. Conclusion}

As I mentioned earlier in this chapter, the South African Constitution and its Bill of Rights, coupled with an impressive equality and human rights jurisprudence generated by the Constitutional Court, has been admired widely. I tried to demonstrate that healthy synergy between international legal principles and the South African constitutional principles, and how each set injected into the other the possibilities of human rights transformation. I also tried to demonstrate how the Constitutional Court has been strategically mindful of its mandate under the Constitution to consider international and foreign law, and to use international law to pursue the agenda of transformation envisioned by the Constitution. But

${ }^{130}$ Study Concerning the Right to Restitution, Compensation and Rehabilitation for Victims of Gross Violations of Human Rights and Fundamental Freedoms, Final Report Submitted by Mr. Theo Van Boven, Special Rapporteur, United Nations Human Rights Commission, U.N. Doc. E/ CN.4/Sub.2/1993/8 (July 2, 1993).

${ }^{131} \mathrm{~S}$. AFr. Const. 1996, supra note 30, $\$ 22$.

${ }^{132}$ See, e.g., John Dugard, Reconciliation and Justice: The South African Experience, 8 TRANSNAT'L Legal \& Contemp. Probs. 277 (1998); see also Ziyad Motala, The Constitutional Court's Approach to International Law and its Method of Interpretation in the Amnesty Decision': Intellectual Honesty or Political Expediency? 21 SAYIL 29 (1996). 
the Court has also been mindful of the contextual realities of South Africa, and has attempted to cultivate an indigenous human rights jurisprudence, that will take root in South Africa even though it draws from international and comparative human rights principles.

Of course the human rights project in South Africa extends beyond the text of the Bill of Rights or the deliberations of the Constitutional Court and other legal bodies mandated to interpret and enforce the Bill of Rights. The reality of poverty and the gross economic inequalities so pervasive in South Africa threaten to undermine the constitutional project. Moreover, the increasingly privatized nature of the South African economy may corrode the possibilities generated by the incorporation of socio-economic rights in the Constitution. In order for the formal constitutional project to be effective, at the minimum it has to give rise to a culture of human rights.

Just as apartheid was a concern of the global community, so too the contemporary constitutional project in South Africa generates significant global interest. One aspect of the transformation process, that is, the formal incorporation of human rights is underway. The challenge for South Africa is to translate those formal rights into tangible political, social and economic rights. 